\title{
Pentagamavunon-0 menurunkan Ekspresi Cyclooxygenase 2 dan Jumlah Sel Epitel Luminal Endometrium Tikus yang Diinduksi dengan Luteinizing Hormone
}

\section{Pentagamavunon-0 decreases Endometrial Cyclooxygenase 2 Expression and the Amount of Endometrial Epithelial Cells of Rats Induced with Luteinizing Hormone}

\author{
Soraya Rahmanisa ${ }^{1}$, Muhartono $^{2}$ \\ ${ }^{1}$ Bagian Biologi Medik Fakultas Kedokteran Universitas Lampung \\ ${ }^{2}$ Bagian Patologi Anatomi Fakultas Kedokteran Universitas Lampung Bandar Lampung
}

\begin{abstract}
ABSTRAK
Pentagamavunon-0 (PGV-0) atau 2,5-bis-(4'-hidroksi-3'-metoksi-benzilidin siklopentanon merupakan senyawa analog kurkumin dengan perubahan struktur pada gugus $\beta$ diketon menjadi gugus monoketon. Aktivitas dan mekanisme PGV-0 pada sistem reproduksi khususnya terhadap ekspresi Cyclooxygenase 2(COX-2) dan ketebalan endometrium belum dapat dijelaskan. Serbuk PGV-0 dilaporkan mempunyai aktivitas biologis lebih baik daripada senyawa asalnya. Tujuan penelitian ini adalah untuk mengkaji pengaruh PGV-0 terhadap ekspresi COX-2, ketebalan endometrium, dan jumlah sel epitel luminal endometrium Rattus norvegicus yang diinduksi dengan Luteinizing Hormone (LH). Subjek penelitian ini adalah 30 ekor tikus putih betina Sprague dawley umur 28 hari setelah diinduksi dengan pregnant mare's serum gonadotropin. Setelah semua tikus ovulasi, tikus kemudian diberikan PGV-0 dosis 55,2mg/kgBB selama 4 hari setelah diinduksi dengan LH pada hari pertama perlakuan. Pada kelompok kontrol diberikan senyawa pelarut PGV-0 yaitu Carboxyl Metil Cellulose (CMC). Pada umur 34 hari hewan coba dikorbankan untuk diambil uterusnya dan dibuat sediaan histologi dan imunohistopatologik. Hasil penelitian menunjukkan pemberian PGV-0 dosis 55,2mg/kgBB berpengaruh nyata menurunkan ekspresi COX-2 $(p<0,05)$ dan jumlah sel epitel luminal endometrium $(p<0,05)$ tetapi tidak berpengaruh nyata terhadap penebalan endometrium tikus yang diinduksi dengan $\mathrm{LH}(\mathrm{p}<0,05)$.
\end{abstract}

Kata Kunci: COX-2, ketebalan endometrium, LH, PGV-0

\begin{abstract}
Pentagamavunon-0 (PGV-0) or 2,5-bis-(4'-hydroxy-3'-methoxy-benzylidene cyclopentanone is a curcumine synthetic analog compound with structure modification on $B$ diketone group into monocheton group. PGV-O activity and mechanism in reproductive system especially in expression of Cyclooxygenase 2(COX-2) and endometrium thickness have never been elucidated. Pentagamavunon-0 (PGV-0) powder is reported to have better biological activity than the original compound. The aim of this research is to study the effect of PGV-O on the expression of COX-2, the endometrium thickness, and the amount of epithelial cells in Rattus norvegicus induced with Luteinizing Hormone (LH). Subjects in this study were 30 Sprague Dawley Rats aged 28 days after being induced with pregnant mare's serum gonadotropin (PMSG). After ovulated, rats were treated with 55,2mg/ $\mathrm{kgBW}$ PGV-O for 4 days after they were stimulated by luteinizing hormone (LH) on the first treatment day. Control group was administered with solution buffer for PGV-0, namely Carboxyl Metil Cellulose. At the age of 34 days, all rats were sacrificed and the uteri were taken to make a sample of histology and immunohistology. Based on the result of the research, the administration of PGV-0 in dose 55,2mg/kgBW significantly decreases the expression of $\mathrm{COX}-2(p<0,05)$ and the amount of luminal epithelium endometrium $(p<0,05)$, but insignificantly affects the endometrium thickness of rats induced with $\mathrm{LH}(p<0,05)$.
\end{abstract}

ABSTRACT

Keywords: COX-2, endometrium thickness, $L H, P G V-0$

Jurnal Kedokteran Brawijaya, Vol. 28, No. 4, Agustus 2015; Korespondensi: Soraya Rahmanisa. Bagian Biologi Medik Fakultas Kedokteran Universitas Lampung, Jl. Prof. Dr. Soematri Brojonegoro No. 1 Gedung Meneng Bandar lampung Tel. (721) 701609 Email: sorayarahmanisa1204@gmail.com 


\section{PENDAHULUAN}

Terjadinya proses pembuahan (fertilisasi) tidak lepas dari peranan endometrium dalam uterus dan keseimbangan hormon estrogen dan progesteron yang siklik. Estrogen dihasilkan oleh ovarium sebagai respon terhadap hipotalamus, sedangkan progesteron berfungsi untuk mempertahankan blastosis pada saat implant di dalam endometrium. Kedua hormon ini sangat berpengaruh penting bagi proses reproduksi (1).

Endometrium sendiri menghasilkan prostaglandin serupa dengan hormon lokal yang produksinya dapat dipicu oleh karena adanya enzim tertentu yaitu enzim siklooksigenase (COX) (2). Prostaglandin, berperan sebagai hormon lokal yang berperan sebagai vasomotor yang memperantarai vasodilatasi dan vasokonstriksi, juga berpengaruh pada kontraksi otot polos dan permeabilitas pembuluh darah, sedangkan prostaglandin yang dihasilkan oleh uterus, termasuk dari endometrium dan myometrium, diduga berperan penting dalam pengaturan siklus estrus, implantasi embryo, dan inisiasi kelahiran (3).

Terdapat dua jenis enzim COX, yaitu COX-1 dan COX-2. Cyclooxygenase-1 terdapat hampir pada semua jaringan, terutama pada saluran pencernaan dan ginjal, yang mempertahankan fungsi fisiologis normal jaringan serta menginduksi fungsi platelet (4), sedangkan COX-2 dianggap sebagai enzim pro-inflammasi yang diinduksi oleh sejumlah faktor pertumbuhan dan sitokin. Ekspresi COX-2 merupakan suatu variasi respon fisiologis tubuh pada organisme, misalnya pada kondisi perlukaan jaringan dan inflamasi (5). Protein COX bertanggung jawab dan menjadi pembatas dalam tahapan pembentukan prostaglandin. Protein COX bertugas mengubah asam arakhidonat menjadi endoperoxidase intermediate (PGH2) yang kemudian akan diubah menjadi PGs oleh enzim sinthase spesifik. Terdapat dua bentuk isoform dari COX, yaitu COX-1 dan COX-2, yang dikode oleh gen yang terpisah (6). Secara umum, COX-1 adalah gen yang aktif secara konstitutif yang dibutuhkan untuk mekanisme seluler sel, sedangkan pada sisi lain, COX-2 didukung oleh sejumlah stimulus yang berbeda (7).

Luteinizing Hormone (LH) berperan dalam pengaturan enzim siklooksigenase dan sintesis prostanoid dalam saluran reproduksi, endometrium, miometrium, serviks, dan vena uterus (8). Siklooksigenase merupakan enzim yang berperan dalam proses perubahan/biosintesis prostaglandin (PGF2 $\alpha$ ) terutama dalam endometrium (9). Reseptivitas endometrium dapat tergantung pada waktu dan ekspresi dari satu set gen dan periode implantation window yang melibatkan interaksi molekuler antara blastosis dan endometrium. Sebagai contoh, pada tikus sel-sel epitel endometrium mengekspresikan karbohidrat tipe-H, dan lapisan ektoderm embryonik membutuhkan kemampuan untuk mengikat struktur tipe $\mathrm{H}-1$ selama waktu implantasi (10).

Beberapa molekul spesifik diketahui berperan pada reseptivitas endometrium hingga tercapainya implantasi oleh blastosis. Banyak perubahan pada struktur morfologi dan aktivitas enzim, begitu juga dengan ekspresi protein spesifik, seperti komplemen C3, MUC1, PP12, prolaktin, cathepsin D, $\alpha 1-P E G, \alpha 2-P E G$, berbagai molekul integrin, sitokin dan heat shock protein, dapat dijelaskan selama fase sekretori pada endometrium manusia. Beberapa molekul yang sangat berperan penting bagi persiapan endometrium untuk menjadi reseptif hingga blastosis menjadi implant, antara lain integrin, interleukin-6,
MUC-1, trophinin, dan tastin yang mempengaruhi reseptivitas endometrium (11).

Pentagamavunon-0 (PGV-0) atau yang lebih dikenal dengan nama kimia 2,5-bis-(4'-hidroksi-3-metoksi benzilidin) siklopentanon merupakan salah satu modifikasi struktur senyawa kurkumin pada rantai tengah maupun bagian aromatiknya yaitu modifikasi gugus asetil aseton diganti dengan siklopentanon (12). PGV-0 merupakan senyawa antiinflamasi turunan kurkumin, berasal dari hasil sintesis dan masih merupakan calon bahan obat. Senyawa ini memiliki sifat antiinflamasi yang kuat dan memiliki toksisitas sangat rendah (13). Penelitian ini bertujuan untuk mengetahui efek PGV-0 terhadap ekspresi COX-2, ketebalan dan jumlah sel epithel lumina pada endometriumtikus yang diinduksi dengan $\mathrm{LH}$.

\section{METODE}

Dilakukan penelitian eksperimental secara in vitro terhadap 30 ekor tikus Sprague dawley umur 28 hari setelah diinduksi ovulasi dengan PMSG 10 IU. LH diberikan bersamaan pada umur 30 hari secara intraperitoneal pada tiap kelompok perlakuan, sebanyak 10 I.U dan PGV-0 diberikan dengan 1 dosis pada hewan coba yaitu 55,2 $\mathrm{mg} / \mathrm{kg}$ bb, selama 4 hari. Untuk analisis immunositokimia ekspresi COX-2 dipulas dengan menggunakan (biotinylated antimouse Ig antibody) (SantaCruz Biotechnology Inc., CA). Penghitungan jumlah sel yang positif mengekspresikan COX-2 dilakukan secara langsung pada layar monitor (Mitsubishi) dengan perbesaran 1000 Xpada setiap lapang pandang dengan 3 coverslip untuk masing-masing perlakuan. Sitoplasma sel yang mengekspresikan COX-2 akan memberikan warna coklat karena digunakan kromogen DAB. Ketebalan endometrium dapat diamati dengan mengukur tebal pada sediaan jaringan uterus dengan pewarnaan imunositokimiadari permukaan luminal sampai batas miometrium dengan satuan mikrometer $(\mu \mathrm{m})$. Setiap tikus dinilai 3 jaringan dan setiap jaringan dinilai 3 kali pengukuran sehingga diperoleh 9 data tebal endometrium untuk masing-masing hewan coba, kemudian dicari rata-rata masing-masing kelompok. Jumlah sel epitel luminal adalah jumlah sel epitel yang melingkupi permukaan endometrium yang dihitung secara langsung pada layar monitor dengan perbesaran $1000 \mathrm{X}$.

\section{HASIL}

Hasil penelitian memperlihatkan bahwa ekspresi COX-2 di endometrium tikus yang diinduksi dengan LH mengalami penurunan. Hal ini memperlihatkan bahwa PGV-0 menunjukkan aktivitasnya sebagai inhibitor siklooksigenase (COX) sehingga terjadi hambatan biosintesis $\mathrm{PGF}_{2} \alpha$. Induksi $\mathrm{LH}$ yang diberikan dengan PGV-0 menghasilkan ekspresi COX-2 lebih rendah secara bermakna dibandingkan dengan kelompok yang mendapat perlakuan PGV-0 maupun LH saja. Hasil penelitian menunjukkan bahwa PGV-0 dosis 55,2 $\mathrm{mg} / \mathrm{kgbb}$ yangdiinduksi LH menurunkan ekspresi COX-2. Peningkatan ekspresi COX-2 yang diinduksi LH dihambat secara bermakna oleh PGV-0. PGV-0 dosis $55,2 \mathrm{mg} / \mathrm{kgbb}$ menunjukkan rerata persentase ekspresi COX-2 lebih rendah daripada kelompok perlakuan yang hanya diinduksi LH, dan berbeda secara bermakna dibandingkan dengan kelompok yang diberi perlakuan $\mathrm{LH}+\mathrm{CMC}$, tetapi lebih tinggi dan berbeda secara bermakna dibandingkan dengan kelompok kontrol tanpa perlakuan PGV-0. 
Ekspresi enzim COX-2 dalam endometrium sangat erat kaitannya dengan produksi $\mathrm{PGE}_{2}$ yang merangsang proliferasi sel-sel dalam endometrium. Dengan adanya LH diharapkan dapat memacu sintesis protein dalam endometrium sehingga dapat mengekpresikan mRNA dengan adanya ekspresi COX-2 yang kuat dalam endometrium. PGV-0 dosis $55,2 \mathrm{mg} / \mathrm{kgbb}$ aktivitasnya tampak sebagai antigonadotropik yaitu menurunkan kerja induksi LH.<smiles>COc1cc(C=C2CC=C(C=C3C=CC(O)C(OC)C3)C2=O)ccc1O</smiles>

Gambar 1. Struktur kimia senyawa pentagamavunon-0

Tebal endometrium tikus yang diberikan PGV-0 dosis $55,2 \mathrm{mg} / \mathrm{kgbb}$ meningkat secara bermakna dibandingkan dengan semua kelompok kontrol. Induksi LH dalam meningkatkan tebal endometrium juga tidak dihambat oleh PGV-0. Hasil penelitian ini menunjukkan induksi LH dan pemberian PGV-0 dosis $55,2 \mathrm{mg} / \mathrm{kgbb}$ mampu meningkatkan tebal endometrium. Enzim COX, PGE2, dan reseptor EP mengatur remodelling vaskuler dengan menginduksi angiogenesis. Ekspresi COX-2 yang berlebih akan menyebabkan meningkatnya produksi $\mathrm{PGE}_{2}$. COX-2, EP2, dan faktor pemacu angiogenik seperti VEGF, angiopoietin-1, dan angiopoietin-2 berperan dalam induksi angiogenesis dengan membentuk struktur tubuler dan pembuluh darah baru pada sel-sel endothelial. Angiogenik Growth Factor di endometrium yang berperan yaitu EGF, TGF- $\alpha$, TGF- $\beta$, TNF- $\alpha$, angiogenin, fibroblas growth factor, VEGF, prostaglandin E2, monobutyrin. Molekul tersebut berperan untuk menginduksi proliferasi sel endotelial, migrasi, dan pembentukan tubulus juga memfasilitasi perubahan matriks seluler yang dibutuhkan untuk pembentukan pembuluh darah yang baru (7).

Ekspresi COX-2 dalam Endometrium. Hasil penelitian menunjukkan bahwa ekspresi COX-2 di endometrium tikus yang diinduksi dengan LH menurun setelah mendapat perlakuan PGV-OInduksi LH tanpa pemberian PGV-0 terbukti meningkatkan ekspresi COX-2 endometrium, tetapi lebih tinggi bila dibandingkan dengan kelompok yang hanya diberi perlakuan PGV-0 saja maupun kelompok yang diberi LH+PGV-0. Rerata ekspresi COX-2 di endometrium Rattus norvegicus dapat dilihat pada Tabel 1.

Tabel 1. Rerata (M $\pm S D)$ Ekspresi COX-2 di endometrium tikus setelah pemberian PGV-0 dosis $55,2 \mathrm{mg} / \mathrm{kgbb}$ dengan induksi LH 10 IU

\begin{tabular}{clc}
\hline No. & \multicolumn{1}{c}{ Perlakuan } & $\begin{array}{c}\text { Rerata }(\mathbf{M} \pm \text { SD) Ekspresi COX-2 (\%) di } \\
\text { endometrium tikus }\end{array}$ \\
\hline 1. & Aquades & $16,67 \pm 2,16^{\mathrm{a}}$ \\
2. & LH+Aquades & $22,18 \pm 1,83^{\mathrm{a}}$ \\
3. & CMC & $20,97 \pm 3,53^{\mathrm{a}}$ \\
4. & LH+CMC & $59,72 \pm 16,28^{\mathrm{c}}$ \\
5. & PGV-0+CMC & $41,68 \pm 8,87^{\mathrm{b}}$ \\
6. & LH+PGV-0+CMC & $28,27 \pm 3,90^{\mathrm{a}}$ \\
\hline
\end{tabular}

Keterangan: Notasi $(a, b, c, d)$ yang berbeda menunjukkan perbedaan bermakna
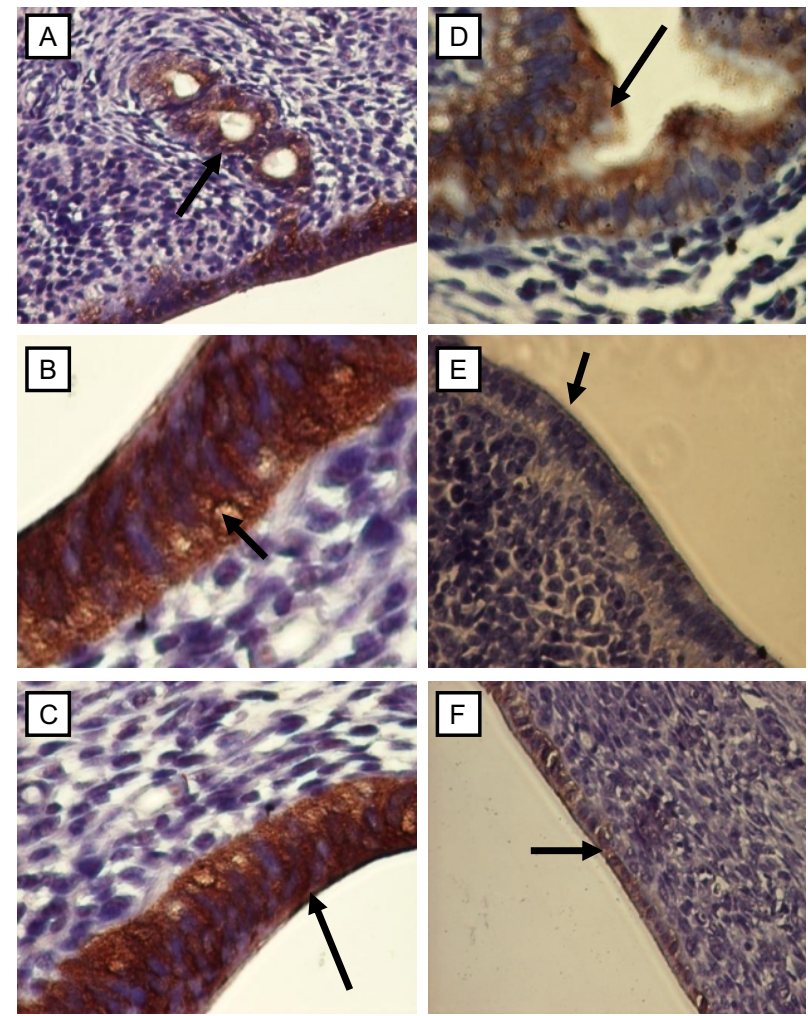

Gambar 2. Imunositokimia ekspresi COX-2 pada endometrium setelah pemberian PGV-0

Keterangan: Pengamatan dengan mikroskop fase kontras perbesaran $1000 x$

A. Aqua

B. $\mathrm{CMC}$

C. PGV-0

D. Aqua $+\mathrm{LH}$

E. $\mathrm{CMC}+\mathrm{LH}$

F. PGV-0+LH

Warna coklat pada sitoplasma menunjukkan adanya ekspresi COX-2

\section{DISKUSI}

Pada penelitian ini PGV-O menunjukkan sifat sebagai antigonadotropik terhadap LH yang tergantung dosis (dose dependent). Hal ini sesuai dengan penelitian terdahulu oleh Hakim (14) yang menyatakan bahwa nilai LD50 PGV-0 lebih besar dari zat antiinflammasi lain termasuk kurkumin. Hal ini dapat diasumsikan bahwa PGV-0 memiliki tingkat keamanan yang baik bahkan lebih baik dari senyawa asalnya. Pemberian PGV-0 pada penelitian ini mampu menghambat ekspresi COX-2 apabila diberikan bersamaan dengan LH, tetapi letak penghambatan belum jelas diketahui, pada dasarnya inhibisi terjadi pada enzim COX sebelum pembentukan adenilat siklase.

Hasil analisis variansi menunjukkan terdapat perbedaan secara bermakna antara kelompok yang mendapat perlakuan PGV-O saja dibandingkan dengan PGV-0+LH. Shemesh mengungkapkan bahwa LH akan meningkatkan ekspresi COX-2 di endometrium. Dalam serviks dan endometrium, inkubasi jaringan dengan LH dapat meningkatkan ekspresi siklooksigenase dan produksi PGE2 dalam serviks dan produksi PGF2 $\alpha$ dalam endometrium. Dalam serviks, LH meregulasi ekspresi enzim siklooksigenase dengan mengaktivasi PLC dan adenilat siklase melalui second messenger G-protein. Mekanisme LH dalam menstimulasi COX dalam endometrium diduga akibat aktivasi PLC dan CAMP pada jaringan serviks pada fase luteal sama halnya dengan mekanisme pada ovarium 
dan testes. Mekanisme aksi reseptor LH di endometrium terkait dengan produksi prostaglandin dalam uterus (8).

Luteinizing hormone merupakan stimulator potensial untuk pembentukan PGs di endometrium. Luteinizing hormone memiliki sel target yaitu pada jaringan endometrium, reseptor $\mathrm{LH}$ di endometrium mengaktivasi adenilat siklase (AC) dan fosfolipase C (PLC) dalam dua jalur berbeda. Melalui jalur PLC, LH mengikat reseptor permukaan sel dan mengaktifkan PLC yang akan dipecah menjadi second messenger inisitol trifosfat (IP3) dan Diasil gliserol (DAG). Diasil gliserol akan meningkatkan sintesis PGF dengan meningkatkan aktivitas protein kinase $\mathrm{C}$ (PKC). Protein kinase $C$ kemudian akan mengaktifkan enzim intraseluler yang akan mengaktifkan cPLA2. PKC akan merangsang sintesis PGF2 $\alpha$. PGF akan memacu kontraksi pada otot halus dinding uterus (11).

Aktivasi reseptor $\mathrm{LH}$ di endometrium berhubungan dengan produksi PGF. Reseptor $\mathrm{LH}$ di endometrium manusia terdapat pada sel epitel dan stroma dalam

\section{DAFTAR PUSTAKA}

1. Cunha GR, Cooke PS, and Kurita T. Role of StromalEpithelial Interactions in Hormonal Responses. Archive of Histology Cytology. 2004; 67(5): 417-434.

2. Strowitzki T, Germeyer A, Popovici R, and Wolff MV. The Human Endometrium as a Fertility-Determining Factor. Human Reproduction Update. 2006; 12(5): 617-630.

3. Murdoch WJ, Hansen TR, and McPherson LA. A Review-Role of Eicosanoids in Vertebrate Ovulation. Prostaglandins. 1993; 46(2): 85-115.

4. Marions L and Danielsson KG. Expression of Cyclooxygenase in Human Endometrium during the Implantation Period. Molecular Human Reproduction. 1999; 5(10): 961-965

5. Sirois J, Sayasith K, Brown KA, Stock AE, Bouchard N, and Dore M. Cyclooxygenase-2 and Its Role in Ovulation: A 2004 Account. Human Reproduction Update. 2004; 10(5): 373-385.

6. Matsuzaki S, Canis M, Pouly JL, Wattiez A, Okamura K, and Mage G. Cyclooxygenase-2 Expression in Deep Endometriosis and Matched Eutopic Endometrium. Fertility and Sterility. 2004; 82(5): 1309-1315.

7. Smith WL, Garavito RM, and DeWitt DL. Prostaglandin Endoperoxide H-Synthases-1 and -2. The Journal of Biological Chemistry. 1996; 271(52): 33157-33160.

8. Shemesh M, Mizrachi D, Gurevich M, Stram Y, Shore LS, and Fields MJ. Direct Involvement of Luteinizing jumlah maksimal akan merangsang peningkatan CAMP dan inositol fosfat (IP1, IP2, dan IP3) melalui jalur adenilat siklase (11). Inositol fosfat 3 akan membebaskan $\mathrm{Ca}^{2+}$ intraseluler dengan membuka kanal kalsium pada retikulum endoplasma, $\mathrm{Ca}^{2+}$ berperan penting dalam respon agonist yang menginduksi sintesis prostaglandin. Peningkatan $\mathrm{Ca}^{2+}$ bebas intraseluler akan dibutuhkan untuk aktivasi Calmodulin. Calmodulin akan mengirim sinyal transduksi ke sel-sel dan jaringan dengan berinteraksi melalui protein kinase $\mathrm{CaM}-\left(\mathrm{Ca}^{2+} /\right.$ calmodulin dependen). Peningkatan jumlah second messenger ini berhubungan dengan peningkatan konsentrasi siklooksigenase di endometrium (COX-2) dan produk metabolit PGF. Dapat disimpulkan bahwa pemberian PGV-0 dosis 55,2 mg/kgbb pada endometrium tikus yang diinduksi dengan $\mathrm{LH}$ berpengaruh nyata menekan ekspresi COX-2 dan menurunkan jumlah sel epitel luminal endometrium, tetapi tidak memberikan perubahan terhadap ketebalan endometrium.

Hormone in Uterine Function. Reproduction Domestical Animals. 2000; 35(3-4): 163-166.

9. Kim JJ, Wang J, Bambra C, Das SK, Dey SK, and Fazleabas AT. Expression of Cyclooxygenase-1 and -2 in the Baboon Endometrium during the Menstrual Cycle and Pregnancy. Journal of Endocrinology. 1999; 140(6): 2672-2678.

10. Shemesh M, Freidman S, HarelME, and Gurevich M. Induction and Regulation of the Cyclooxygenase in the Bovine Endometrium. Di dalam: Zor M (Ed). Lipid Mediators in Health and Disease. Tel Aviv: Freund Publishing House; 1994: pp. 71-78.

11. Shemesh M. Actions of Gonadotrophins on the Uterus (Review). Reproduction. 2001; 121(6): 835-842.

12. Sardjiman. Sintesa 2,6-Bis (3,5-Dimetil-4-Hidroksi Benzilidin) Sikloheksanon, 2,5-(3,5-dimetil-4Hidroksi Benzilidin) Siklopentanon \& Pentadien-on dan Daya antioksidannya. [Laporan Penelitian]. Universitas Gadjah Mada, Yogyakarta. 1993

13. Sardjiman dan Samhoedi MR. Synthesis of Some New Series of Curcumin, Analogues, Antioxydative, Antiinflammatory, Antibacterial Activities and Qualitative Structure Activity Relationships. [Disertasi]. Universitas Gadjah Mada, Yogyakarta. 2000 .

14. Hakim L. Pharmacokinetics and Biological Activities of a Curcumin Analog-Pentagamavunon-0. Proceeding of The International Symposium on Recent Progress in Curcumin Research. Yogyakarta, 2007; hal. 37-55. 